\title{
COMPARATIVE STUDY OF SEIMIC ANALYSIS OF A NORMAL BUILDING AND BUILDING WITH FLOATING COLUMNS
}

\author{
D. Annapurna ${ }^{1}$, Sriram Nadipelli ${ }^{2}$ \\ ${ }^{1,2}$ Asst. professor of Civil Engineering, M.E scholar, UCE (A), Osmania University, Telangana
}

\begin{abstract}
In urban India buildings with floating column is a typical feature in the modern multistory construction. Floating columns are generally adopted to create more space in the ground floor. Such features are highly undesirable in building built in seismically active areas. The Indian Standard code IS-1893: 2002 (Part-I) defines a number of structural irregularities. Floating column is one of the structural irregularity in buildings.

This project studies the analysis of G+5 story normal building and a G+5 story floating column building for external lateral forces. The analysis is done by the use of E-Tabs software by using equivalent static analysis. It also studies the variation of the both structures by applying the intensities of the past earthquakes i.e., applying the ground motions to the both structures, from that displacement time history values are compared .The present paper deals with the variation of time period, displacement of structure, base shear, seismic weight of building from manual calculations and E-Tabs. For a general column building and floating column building, finding the variations between them and describes what happens when variation may be high or low. This study is to find whether the structure is safe or unsafe with floating column when built in seismically active areas and also to find floating column building is economical or uneconomical.
\end{abstract}

Index Terms - Floating column building, Normal building, E-tabs.

\section{INTRODUCTION}

Now a days multistorey buildings constructed for the purpose of residential, commercial, industrial etc., with an open ground storey is becoming a common feature. For the purpose of parking all, usually the ground storey is kept free without any constructions, except the columns which transfer the building weight to the ground.

For a hotel or commercial building, where the lower floors contain banquet halls, conference rooms, lobbies, show rooms or parking areas, large interrupted space required for the movement of people or vehicles. Closely spaced columns based on the layout of upper floors are not desirable in the lower floors. So to avoid that problem floating column concept has come into existence.

\subsection{Significance of the present work:}

In urban areas, multi storey buildings are constructed by providing floating columns at the ground floor for the various purposes which are stated above. These floating column buildings are designed for gravity loads and safe under gravity loads but these buildings are not designed for earthquake loads. So these buildings are unsafe in seismic prone areas. The paper aims to create awareness about these issues in earthquake resistant design of multi-storeyed buildings.

\subsection{Overview of floating column building:}

This paper deals with the comparison of a G+5 storey building with all columns and a $\mathrm{G}+5$ storey building without edge columns. Here a $\mathrm{G}+5$ building without edge columns is nothing but a floating column building that is the building in which the columns at the edge of ground floor are removed. From the first story to the top storey all columns are present. Then the load transferred by the edge columns is transferred to the interior columns present in the ground storey.

By applying the static loads both the structures are safe. After applying the dynamic loads that is earthquake loads in lateral direction the structure without edge columns is unsafe, that is displacement of this structure is more than the structure with edge columns and stiffness of structure is also less than the structure with edge columns. To make the structure safe size of beams and columns are to be increased. By increasing the dimensions of beams and columns, research is carried out to find whether the structure without edge columns will be safe or not. Also study is carried out to find which structure is economical and the variation of economy between the both buildings can be identified. 
Table 1. Dimensions of the building

\begin{tabular}{|c|c|c|c|}
\hline \multicolumn{4}{|c|}{ Members dimensions } \\
\hline Slab & \multicolumn{2}{|l|}{ thickness } & $150 \mathrm{~mm}$ \\
\hline \multirow[t]{3}{*}{ Beams } & \multicolumn{2}{|l|}{ Normal building } & $300 \mathrm{~mm} \times 400 \mathrm{~mm}$ \\
\hline & \multirow{2}{*}{$\begin{array}{ll}\text { Floating } & \text { column } \\
\text { building } & \end{array}$} & Interior beams & $300 \mathrm{~mm} \times 400 \mathrm{~mm}$ \\
\hline & & Cantilever beams & $650 \mathrm{~mm} \times 850 \mathrm{~mm}$ \\
\hline \multirow[t]{7}{*}{ Columns } & \multicolumn{2}{|l|}{ Normal building } & $350 \mathrm{~mm} \times 500 \mathrm{~mm}$ \\
\hline & \multirow{6}{*}{$\begin{array}{ll}\text { Floating } & \text { column } \\
\text { building } & \end{array}$} & \multirow[t]{2}{*}{ Top 4 floors } & $350 \mathrm{~mm} \times 500 \mathrm{~mm}$ (No.s 32) \\
\hline & & & 900mm x 900mm (No.s 4) \\
\hline & & \multirow[t]{2}{*}{ First floor } & $700 \mathrm{~mm} \times$ 900mm (No.s 32) \\
\hline & & & 900mm x 900mm (No.s 4) \\
\hline & & \multirow[t]{2}{*}{ Ground floor } & 700mm x 900mm (No.s 12) \\
\hline & & & 900mm x 900mm (No.s 4) \\
\hline \multirow[t]{2}{*}{ Brick infill } & \multicolumn{2}{|l|}{ Exterior wall thickness } & $250 \mathrm{~mm}$ \\
\hline & \multicolumn{2}{|l|}{ Interior wall thickness } & $150 \mathrm{~mm}$ \\
\hline \multicolumn{4}{|c|}{ Loads } \\
\hline \multicolumn{3}{|c|}{ Unit weight of concrete } & $25 \mathrm{kN} / \mathrm{m}^{2}$ \\
\hline \multicolumn{3}{|c|}{ Unit weight of brick infill } & $20 \mathrm{kN} / \mathrm{m}^{2}$ \\
\hline \multirow[t]{2}{*}{ Floors } & \multicolumn{2}{|l|}{ Live load } & $4 \mathrm{kN} / \mathrm{m}^{2}$ \\
\hline & \multicolumn{2}{|l|}{ Floor finish } & $2 \mathrm{kN} / \mathrm{m}^{2}$ \\
\hline \multirow[t]{2}{*}{ Roof } & \multicolumn{2}{|l|}{ Floor finish } & $1 \mathrm{kN} / \mathrm{m}^{2}$ \\
\hline & \multicolumn{2}{|l|}{\begin{tabular}{|l|} 
Water proofing \\
\end{tabular}} & $1 \mathrm{kN} / \mathrm{m}^{2}$ \\
\hline \multicolumn{4}{|c|}{ Grade of rebar steel } \\
\hline \multicolumn{2}{|l|}{ Beams } & \multicolumn{2}{|l|}{ Fe415 } \\
\hline \multicolumn{2}{|l|}{ Columns } & \multicolumn{2}{|l|}{ Fe415 } \\
\hline
\end{tabular}

\subsection{Model Studies:}

A ground plus five storeyed $(\mathrm{G}+5)$ normal and a floating column building, with specially moment resisting frames in two orthogonal directions were selected for the study. Both the buildings are considered to be located in Zone III as per IS 1893:2002. The dimensions of beams, columns and slab and also applied loads are summarized in the above table 1 .

\section{- Model 1:}

Here a $\mathrm{G}+5$ building with all edge columns which is nothing but a normal building is considered as model 1 with dimensions of beams as $300 \mathrm{~mm} \mathrm{X} 400 \mathrm{~mm}$ and column as $350 \mathrm{~mm}$ X $500 \mathrm{~mm}$. For the overall building the dimensions of beams and columns are same in both $\mathrm{X}$ and $\mathrm{Y}$ directions.

\section{- Model 2:}

Model 2 building is obtained by removing all the edge columns at ground floor of the model 1 building without changing in the dimensions of beams and columns. Model 2 building members are failed to withstand for the applied gravity loads and lateral loads.

\section{- Model 3:}

As the Model 2 building is failed, so another building is created by changing the dimensions of the members to make the building to withstand for the applied gravity loads and lateral loads. The building with changes in columns and beams is considered as model 3 building. For a Model 3 building, top four floors column dimensions are taken as 350 $\mathrm{mm} \mathrm{X} 500 \mathrm{~mm}$ (32 in No) and $900 \mathrm{~mm} \mathrm{X} 900 \mathrm{~mm}$ (4 in No).First floor may have column size as $700 \mathrm{~mm} \mathrm{X} 900 \mathrm{~mm}$ (32 in No) and $900 \mathrm{~mm} \mathrm{X} 900 \mathrm{~mm}$ (4 in No), ground floor have column sizes as $700 \mathrm{~mm}$ X $900 \mathrm{~mm}$ (12 in No) and 900 $\mathrm{mm}$ X $900 \mathrm{~mm}$ (4 in No). Also all the beams will have 300 $\mathrm{mm}$ X $400 \mathrm{~mm}$ except the projected cantilever beam which are $650 \mathrm{~mm} \mathrm{X} 850 \mathrm{~mm}$.

\section{EQUIVALENT STATIC METHOD:}

Equivalent Lateral force method is one in which all the lateral loads at each floor are calculated manually. Then the structure behaviour is identified by applying the lateral loads acting at each story in $\mathrm{X}$ and $\mathrm{Y}$ directions manually. These lateral loads are calculated by considering the various parameters like the Response reduction factor(R), Zone factor (Z), Importance factor (I), Horizontal acceleration coefficient (Ah), Structural response factor $(\mathrm{Sa} / \mathrm{g})$ and Total seismic weight of building (W) as per the IS code 18932002.

\subsection{For a Normal (Model 1) building:}

Calculated seismic weight of normal building is 
$55252.875 \mathrm{kN}$. Fundamental natural time period $=0.735 \mathrm{sec}$ From time period value by interpolating in IS 1893 of clause 6.4.5 we get $\mathrm{Sa} / \mathrm{g}$ as $1.85 ; \mathrm{Ah}=0.0296$

Base Shear of Building $=1635.4851 \mathrm{kN}$

Calculated base shear is distributed at each floor of the building.

Table 2. Lateral forces at each floor for model 1 building

\begin{tabular}{|l|l|l|}
\hline & $\begin{array}{l}\text { Distributed base shear as } \\
\text { Lateral force to each } \\
\text { floor }(\mathrm{kN})\end{array}$ & $\begin{array}{l}\text { Lateral force at } \\
\text { each joint }(\mathrm{kN})\end{array}$ \\
\hline Terrace & 528.9 & 88.16 \\
\hline $5^{\text {th }}$ floor & 502.9 & 83.82 \\
\hline $4^{\text {th }}$ floor & 321.87 & 53.64 \\
\hline $3^{\text {rd }}$ floor & 181.04 & 30.17 \\
\hline $2^{\text {nd }}$ floor & 80.46 & 13.41 \\
\hline $1^{\text {st }}$ floor & 20.11 & 3.35 \\
\hline
\end{tabular}

As model 2 building also has dimensions as model 1 building the same lateral forces are applied for model 2 building.

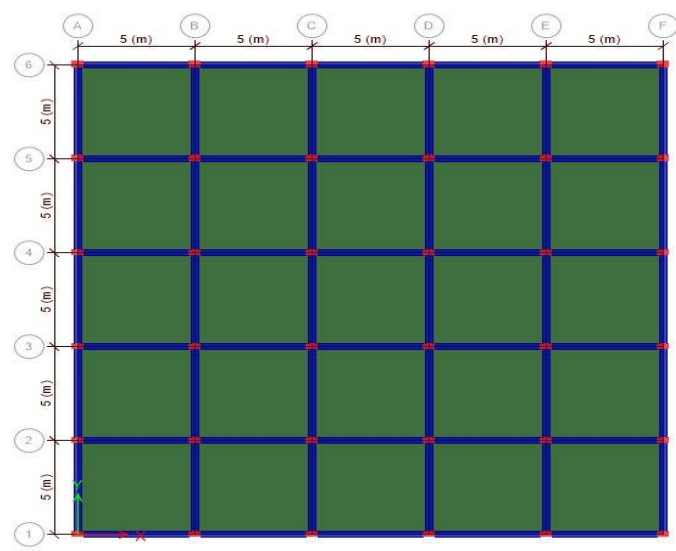

Figure 1. plan of normal building (Model 1)

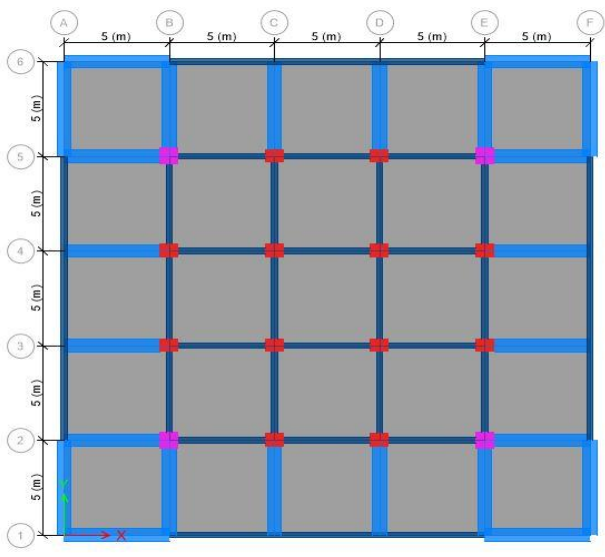

Figure 2.Plan of ground floor of model 3 building

\subsection{For a Floating column (Model 3) building:}

Calculated seismic weight of a floating column building is $63602.75 \mathrm{kN}$.

Fundamental natural time period $=0.735 \mathrm{sec}$

From time period value by interpolating in IS 1893 we get $\mathrm{Sa} / \mathrm{g}$ as 1.85

$\mathrm{Ah}=0.0296$; Base Shear of Building $=1882.64 \mathrm{kN}$.

Table 3. Lateral forces at each floor for Model 3 building

\begin{tabular}{|l|c|}
\hline & $\begin{array}{l}\text { Distributed base shear as lateral force } \\
\text { to each floor }(\mathrm{kN})\end{array}$ \\
\hline Terrace & 626.1 \\
\hline $5^{\text {th }}$ floor & 568.3 \\
\hline $4^{\text {th }}$ floor & 363.72 \\
\hline $3^{\text {rd }}$ floor & 204.64 \\
\hline $2^{\text {nd }}$ floor & 95.26 \\
\hline $1^{\text {st }}$ floor & 23.9 \\
\hline
\end{tabular}

The lateral forces calculated at each storey are to be distributed to all the frames in each storey. Lateral forces are to be distributed to all the frames in ratio of their relative stiffness.

\section{COMPARISIONS}

\section{Comparison based on displacement due to lateral}

load:

By the application of lateral loads in $\mathrm{X}$ and $\mathrm{Y}$ directions the structure can be analysed for various load combinations given by clause 6.3.1.2 of IS 1893:2002.For the given load combinations maximum displacement at each floor is noted in $\mathrm{X}$ and Ydirection and are shown below in the form of a graph.

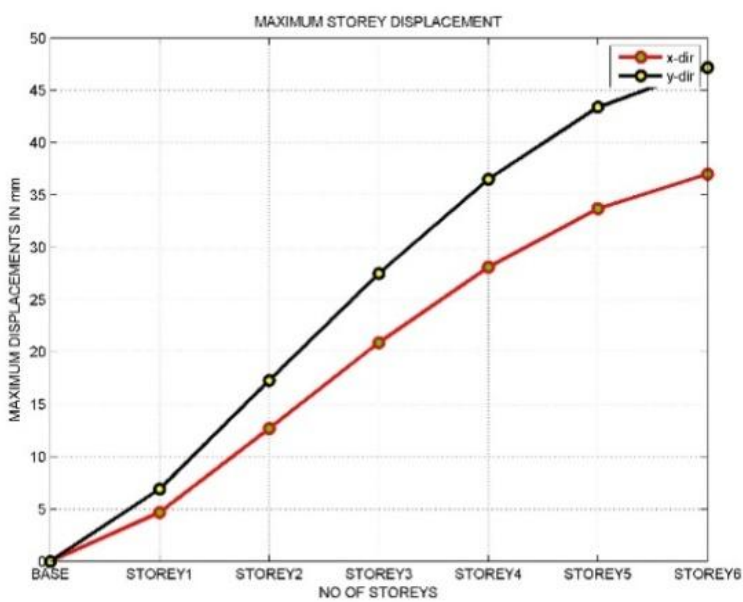

Figure 3. 


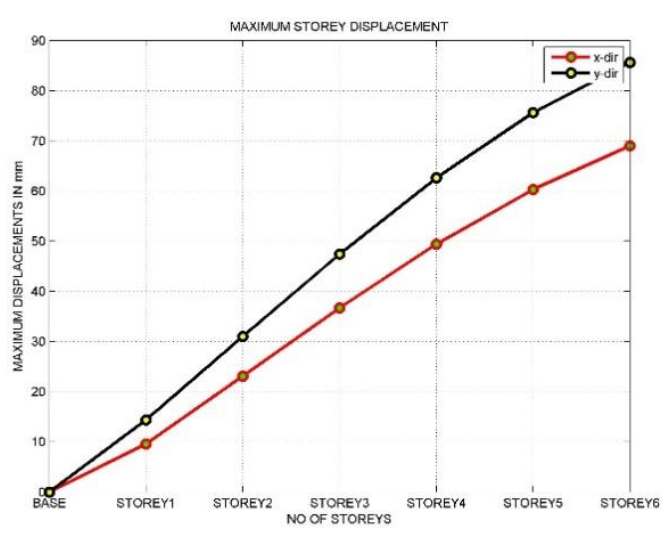

Figure 3 \& Fig 4. Maximum displacement of Model 1 \& Model 2 building at each floor due to lateral loads in $\mathrm{X}$ and $\mathrm{Y}$ directions.

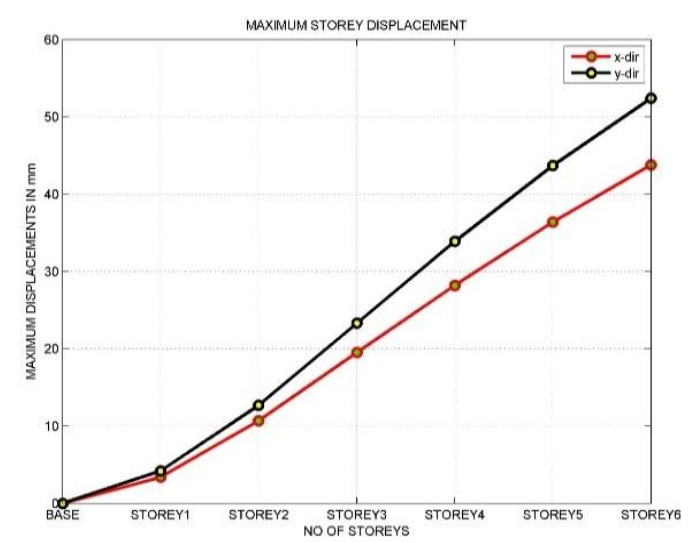

Figure 5. Maximum displacement of Model 3 building at each floor due to lateral loads in $\mathrm{X}$ and $\mathrm{Y}$ directions

From Fig.4, 5 \&6 it can be observed that Model 1 building has less displacement as compared to Model 2 and Model 3 buildings. We can also observe that Model 1 and Model 3 buildings will be safe and no damage starts in the building because the top floor displacements are less than safe permissible top floor displacements of $0.4 \% \times$ Total height of the building (h).

\section{Comparison based on Stiffness:}

The stiffness of all the three models can be calculated and compared as per the table 5 of IS 1893:2002 (part 1) to find whether the above three models are safe from soft storey effect or not.

Table 4. lateral stiffness of the building at each floor

\begin{tabular}{|l|c|c|c|}
\hline \multicolumn{4}{|c|}{ Lateral stiffness for a building } \\
\hline & Model 1 & Model 2 & Model 3 \\
\hline Overall building & 5510204.08 & 4999999.7 & 25539124.81 \\
\hline $6^{\text {th }}$ floor & 918367.3 & 918367.3 & 2346588.78 \\
\hline $5^{\text {th }}$ floor & 918367.3 & 918367.3 & 2346588.78 \\
\hline $4^{\text {th }}$ floor & 918367.3 & 918367.3 & 2346588.78 \\
\hline $3^{\text {rd }}$ floor & 918367.3 & 918367.3 & 2346588.78 \\
\hline $2^{\text {nd }}$ floor & 918367.3 & 918367.3 & 11051895.03 \\
\hline $1^{\text {st }}$ floor & 918367.3 & 408163.2 & 5100874.62 \\
\hline
\end{tabular}

From table 4, the values states that the stiffness of each floor is compared to the stiffness of the storey above and also stiffness is compared to the average stiffness of the three stories above. It is justifiable as per the table 5 of IS 1893: 2002.

Table 5. Variation of lateral stiffness at each floor

\begin{tabular}{|c|c|c|c|c|c|c|}
\hline \multirow[t]{2}{*}{$\begin{array}{l}\text { Floor } \\
\text { Level }\end{array}$} & \multicolumn{3}{|c|}{$\begin{array}{l}\text { Percentage of variation } \\
\text { of lateral stiffness of } \\
\text { floor to avg. of the three } \\
\text { storeys }\end{array}$} & \multicolumn{3}{|c|}{$\begin{array}{l}\text { Percentage of variation of } \\
\text { lateral stiffness of floor } \\
\text { to the above floor }\end{array}$} \\
\hline & $\begin{array}{l}\text { Model } \\
1\end{array}$ & $\begin{array}{l}\text { Model } \\
2\end{array}$ & $\begin{array}{l}\text { Model } \\
3\end{array}$ & $\begin{array}{l}\text { Model } \\
1\end{array}$ & $\begin{array}{l}\text { Model } \\
2\end{array}$ & $\begin{array}{l}\text { Model } \\
3\end{array}$ \\
\hline $\begin{array}{l}6^{\text {th }} \\
\text { floor }\end{array}$ & & & & & & \\
\hline $\begin{array}{l}5^{\text {th }} \\
\text { floor }\end{array}$ & 100 & 100 & 100 & 100 & 100 & 100 \\
\hline $\begin{array}{l}4^{\text {th }} \\
\text { floor }\end{array}$ & 100 & 100 & 100 & 100 & 100 & 100 \\
\hline $\begin{array}{l}3^{\text {th }} \\
\text { floor }\end{array}$ & 100 & 100 & 100 & 100 & 100 & 100 \\
\hline $\begin{array}{l}2^{\text {nd }} \\
\text { floor }\end{array}$ & 100 & 100 & 470 & 100 & 100 & 470 \\
\hline $\begin{array}{l}1^{\text {st }} \\
\text { floor }\end{array}$ & 100 & 44.4 & 97.1 & 100 & 44.4 & 46.15 \\
\hline
\end{tabular}

As per clause 7.1 from table 5 of IS 1893-2002, it states that if the lateral stiffness is less than 70 percent of the storey above or less than 80 percent of the average of the lateral stiffness of the three storeys above, then it will be said to have soft storey effect. It also states that if the lateral stiffness is less than 60 percent of that of the storey above or less than 70 percent of the average stiffness of the three storeys above, then it is said to have extreme soft storey effect. From results we concluded that the lateral stiffness of Model 2 and model 3 building is less than 60 percent, so they suffer from soft storey effect.

\section{Comparison of quantity of steel and concrete:}

For the three model buildings, a comparison of quantity of steel and concrete are made based on the results obtained by the analysis of the both buildings. Here the quantity of steel and concrete are compared only in the model 1 and model 3 building because the model 2 building is unsafe and also the quantity of steel and concrete is little bit less than the model 1 building. For the model 1 and model 3 only the quantity of steel and concrete in beams and columns are calculated because as the thickness of slab, brick walls and all other are same and the loading is also same then the comparison makes no difference between the two buildings. The sizes of beams and columns are varied in the both buildings so the comparison is based only for beams and columns. 
Table 6. Variation of quantity of rebar steel and concrete for Model 1 and Model 3Buildings

\begin{tabular}{|c|c|l|l|l|}
\hline & & $\begin{array}{l}\text { Model 1 } \\
\text { building }\end{array}$ & $\begin{array}{l}\text { Model 3 } \\
\text { Building }\end{array}$ & $\begin{array}{l}\% \\
\text { variation }\end{array}$ \\
\hline $\begin{array}{c}\text { Quantity of rebar } \\
\text { steel in tonnes }\end{array}$ & beam & 21.1 & 44.8 & 127 \\
\cline { 2 - 4 } & column & 17.7 & 40.81 & \\
\hline $\begin{array}{c}\text { Quantity of } \\
\text { concrete in } \mathrm{m}^{3}\end{array}$ & beam & 216 & 527 & 121 \\
\cline { 2 - 4 } & column & 132 & 243 & \\
\hline
\end{tabular}

From the above table it is noticed that the quantity of rebar steel of model 3 building is $127 \%$ (i.e., 46.83Tonnes) more than a model 1 building. Also the quantity of concrete of model 3 building is $121 \%$ (i.e., 422.5 cubic meters) more than a model 1 building. By the above comparison as both the quantity of steel and concrete are more, then the model 3 building is uneconomical than model 1 building.

\section{Comparison based on Time history Analysis:}

In this paper, linear time history analysis is done by applying the past earthquake intensities with motion in $\mathrm{X}$ and $\mathrm{Y}$ direction and displacement due to ground motion in $\mathrm{X}$ and $\mathrm{Y}$ directions are compared for normal and floating column building. Earthquakes such as Elcentro $(\mathrm{PGA}=0.318 \mathrm{~g}), \quad$ Bhuj $\quad(\mathrm{PGA}=0.104 \mathrm{~g})$ and Huston $(\mathrm{PGA}=1.66 \mathrm{~g})$ are applied. Here PGA denotes peak ground acceleration of that earthquake.

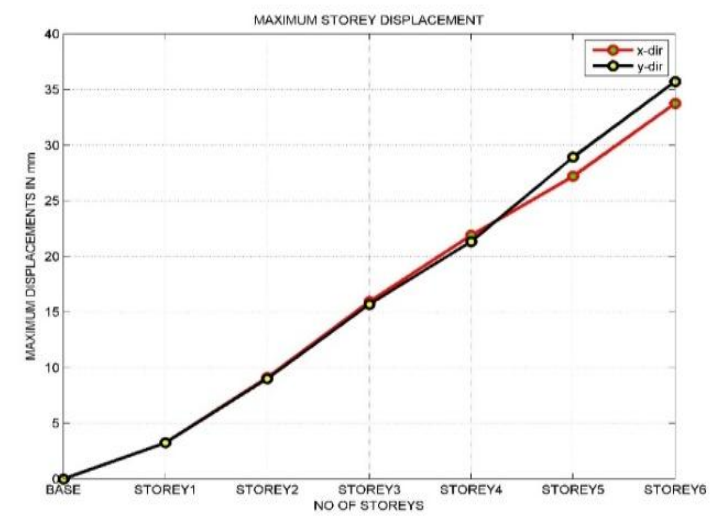

Figure 6

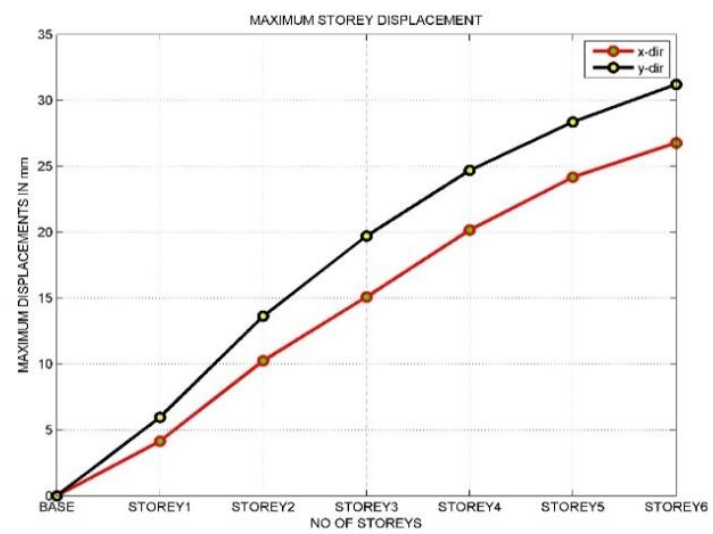

Figure 6 \& 7 Comparision of model 1 and model 2 building due to Elcentro ground motion in $\mathrm{X}$ and $\mathrm{Y}$ directions.

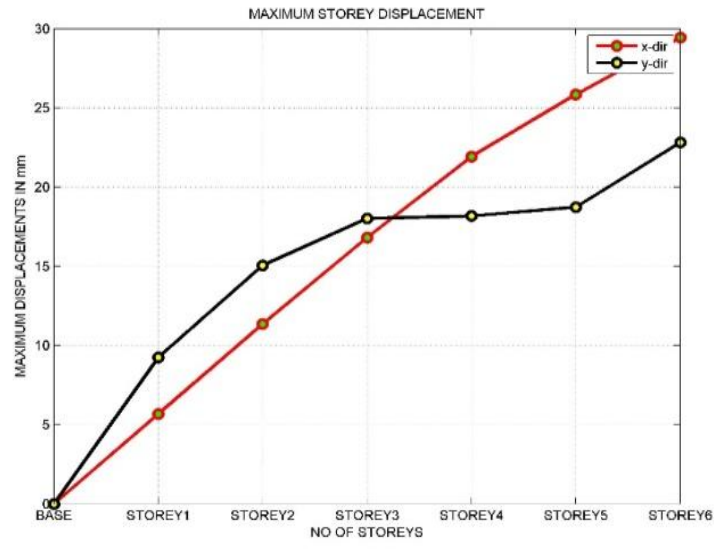

Figure 8

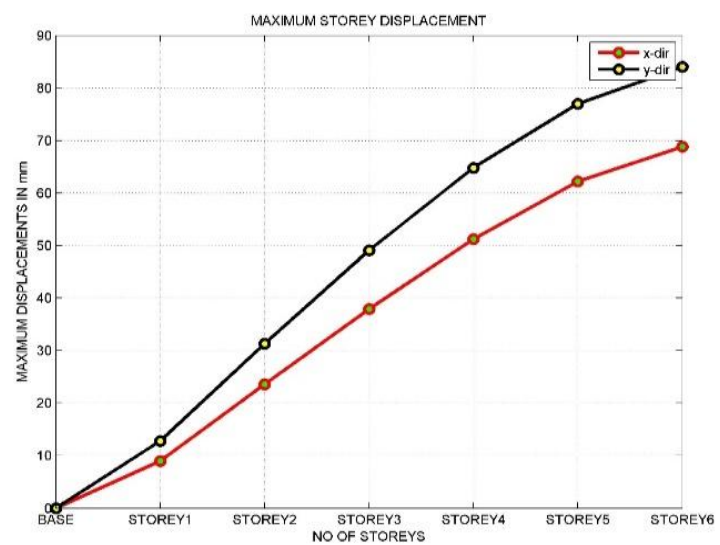

Figure 8. Comparison of model 3 building Figure 9. Comparison of model 1 building due to due to Elcentro ground motion Bhuj ground motion

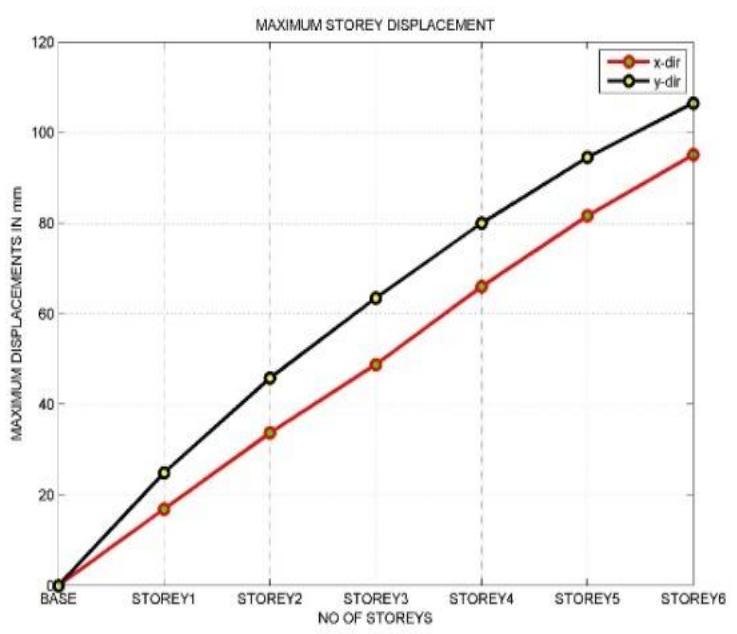

Figure 10. Comparison of model 2 Building due to Bhuj ground motion 


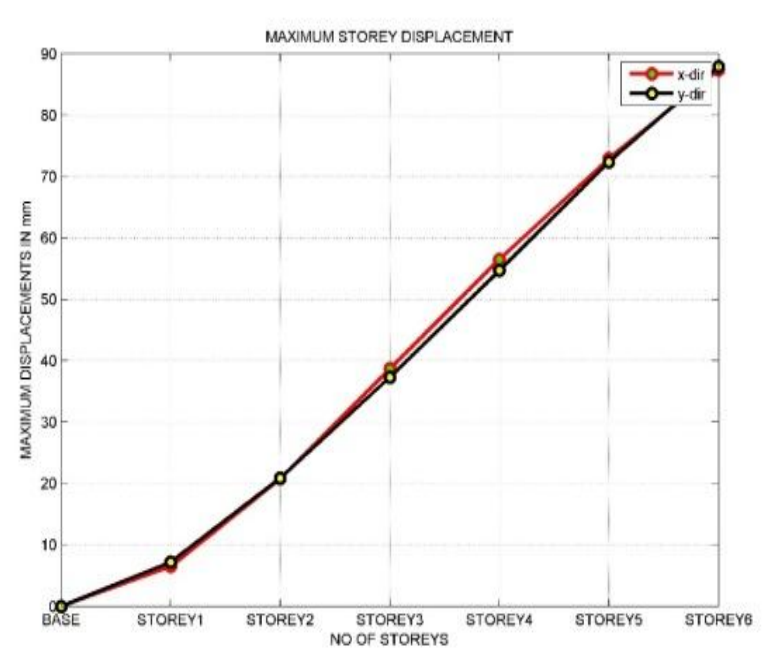

Figure 11. Comparison of model 3 building due to Bhuj ground motion

\section{CONCULSIONS:}

By the application of lateral loads in $\mathrm{X}$ and $\mathrm{Y}$ direction at each floor, the displacements of Model 2 and Model 3 building in $\mathrm{X}$ and $\mathrm{Y}$ directions due to lateral loads are more than displacements of model 1 building. So the Floating column buildings are unsafe for construction when compared to a Normal building.

By comparing model 2 and model 3 building, we can say that floating column building can be made safe by increasing the size of transfer girder beams and size of columns adjacent to floating columns to which finally load is transferred.

By the calculation of lateral stiffness at each floor for the buildings, it is observed that Model 2 and Model 3 buildings that are for buildings with floating columns will suffer from extreme soft storey effect, where Model 1 (Normal building) is free from soft storey effect. So the Floating column building is unsafe.

After the analysis of building and comparing the quantity of steel and concrete for Model 1 and Model 3 building, from which it is identified that Model 3 (Floating column) building has $127 \%$ more quantity of rebar steel and $121 \%$ more concrete quantity than Model 1(Normal) building. So the Floating column building will be uneconomical when compared to Normal building.

From the time history analysis it is noticed that the Model 2 and Model 3 (Floating column) building is having more displacements than Model 1 (Normal) building. So Floating column building is unsafe than a Normal building.

\section{REFERENCES}

[1] PrernaNautiyal, Saleem Akhtar and GeetaBatham (2014), "Seismic response evaluation of RC Frame Building with floating column considering different soil conditions", International Journal of Current Engineering and Technology, Volume 4, January 2014.

[2] Sabah Farheen, BabuS.Munda and Amlan K. Sengupta (2014), "Seismic Forces in members supporting floating columns in a typical reinforced concrete multi - storeyed building", Indian Concrete Journal, March 2014.

[3] PratyushMalaviya, Saurav (2014), “ Comparative study of effect of floating columns on the cost analysis of a structure designed on STAAD Pro V8i", International Journal of Current Engineering and Technology, Volume 5, Issue 5, May 2014.

[4] Srikanth.M.K, Yogeendra, R. Holebagilu (2014) "Seismic Response Complex Buildings with floating column for Zone - II and Zone - V, International Journal of Engineering Research online, Vol.2, Issue.2, July 2014

[5] Onkar V. Sapate (2012) "Inter-Relationship between Moment Values of Columns in a building with different architectural complexities and different seismic zones", International Journal of Engineering Research online, Vol.5, Issue.2, December 2012.

[6] Poonam, Anil Kumar and Ashok K. Gupta (2012) "Study of Response of Structurally Irregular Building Frames to Seismic Excitations", International Journal of Civil, Structural, Environmental and Infrastructure Engineering Research and Development, Vol.2, Issue 2, 2012.

[7] SukumarBehra (2012) "Seismic Analysis of Multi Storied Building with Floating Column", Department of Civil Engineering, National Institute of Techonology, Odisha.

[8] Niroomandi, Maheri, MaheriandMahini (2010) "Seismic performance of ordinary RC frames retrofitted at joints by FRP sheets". Engineering Structures 32 (2010) 2326- 2336.

[9] Garcia Reyes, Hajirasouliha Iman, PilakoutasKypros, (2010),"Seismic behaviour of deficient RC frames strengthened with CFRP composites". Engineering Structures 32 (2010) 3075-3085.

[10] Mortezaei A., Ronagh H.R., Kheyroddin A. (2009), "Seismic evaluation of FRP strengthened RC buildings subjected to near-fault ground motions having fling step". Composite Structures 92 (2010) 1200-1211

[11] Bardakis V.G., Dritsos S.E. (2007), "Evaluating assumptions for seismic assessment of existing buildings “, Soil Dynamics and Earthquake Engineering 27 (2007) 223-233. 